\title{
Letter to Editor on "Comparison Between Endoscopic Biliary Stenting Combined with Balloon Dilation and Balloon Dilation Alone for the Treatment of Benign Hepaticojejunostomy Anastomotic Stricture"
}

\author{
Massimiliano Mutignani $^{1} \cdot$ Lorenzo Dioscoridi $^{1}$ (D) - Francesco Pugliese ${ }^{1}$ - Angelo Italia ${ }^{1}$ - Marcello Cintolo ${ }^{1}$. \\ Giulia Bonato $^{1}$ • Aurora Giannetti ${ }^{1}$. Edoardo Forti ${ }^{1}$
}

Received: 24 August 2019 / Accepted: 27 October 2019 / Published online: 19 November 2019

(C) 2019 The Society for Surgery of the Alimentary Tract

Dear Editor,

We read with great interest the article by Tomoda et al. about the evaluation of the outcomes of endoscopic treatment for benign hepaticojejunostomy anastomotic stricture. ${ }^{1}$

We confirmed the importance of stent deployment in the treatment of this adverse event, in line with the available literature. ${ }^{2,3}$ We would like to briefly focus on the main reason for this consideration.

Benign bilio-digestive anastomotic strictures are different from biliary post-OLT (orthotopic liver transplantation) anastomotic strictures, post-cholecystectomy strictures and biliary strictures related to chronic pancreatitis; the latter three types, in fact, are pure biliary strictures.

However, in hepaticojejunostomy, there are two different tissues involved, the jejunal one and the biliary one. Thus, the stenosis is related to fibrotic reaction of both the tissues in the critical hypovascularized setting of the anastomosis.

On one hand, considering the biliary component, stenting should be suggested as for the other benign stricture. ${ }^{4}$ On the other hand, considering the jejunal component, stenting should be recommended too because, as in intestinal benign anastomotic strictures, it leads to a more gradual and longlasting dilation than balloon dilation alone. Moreover, short self-expandable metal stenting is as effective as plastic multistenting, requiring a smaller number of interventions, ${ }^{3}$ more wide dilation and lower risk of obstructive cholangitis. ${ }^{5}$

\section{Compliance with Ethical Standards}

Conflict of Interest The authors declare that they have no conflict of interest.

\section{References}

1. Tomoda T, Kato H, Miyamoto K, et al. Comparison between endoscopic biliary stenting combined with balloon dilation and balloon dilation alone for the treatment of benign hepaticojejunostomy anastomotic stricture. J Gastrointest Surg. 2019. doi: https://doi.org/10. 1007/s11605-019-04297-8.

2. Yun G, Yoon CJ, Seong NJ. Percutaneous treatment of benign bilioenteric anastomotic strictures: temporary covered stent placement versus balloon dilation. Eur Radiol 2018. doi: https://doi.org/ 10.1007/s00330-018-5776-5.

3. Zhang X, Wang X, Wang L, et al. Effect of covered self-expandable metal stents compared with multiple plastic stents on benign biliary stricture: a meta-analysis. Medicine (Baltimore) 2018; 97: e12039.

4. Dumonceau JM, Tringali A, Papanikolau IS, et al. Endoscopic biliary stenting: indications, choice of stents, and results: European Society of Gastrointestinal Endoscopy (ESGE) Clinical Guidelines-updated October 2017. Endoscopy 2018; 50: 910-930.

5. Mutignani M, Forti E, Larghi A, et al. Endoscopic entero-enteral bypass: an effective new approach to the treatment of postsurgical complications of hepaticojejunostomy. Endoscopy 2019. doi: https:// doi.org/10.1055/a-0914-2855.

Publisher's Note Springer Nature remains neutral with regard to jurisdictional claims in published maps and institutional affiliations.

Massimiliano Mutignani

massimiliano.mutignani@ospedaleniguarda.it

1 Digestive and Operative Endoscopy Unit, Niguarda-Ca' Granda Hospital, Piazza dell'Ospedale Maggiore 3, 20121 Milan, Italy 